\title{
Development and Characterization of a Novel Bioresorbable and Bioactive Biomaterial Based on Polyvinyl Acetate, Calcium Carbonate and Coralline Hydroxyapatite
}

\author{
Javier Aragónn"*, Ramón González $z^{a}$, Gastón Fuentes ${ }^{\mathrm{b}}$, Luca Palin ${ }^{\mathfrak{c}}$, Gianluca Croce ${ }^{c}$, Davide Viterbo ${ }^{\mathrm{c}}$

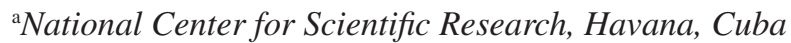 \\ ${ }^{\mathrm{b}}$ Biomaterials Center, University of Havana, Cuba \\ ${ }^{\circ}$ Department of Advanced Science and Technology, University of Piemonte Orientale, \\ "A. Avogadro", Alessandria, Italy
}

Received: June 15, 2010; Revised: December 8, 2010

\begin{abstract}
Coralina ${ }^{\circledR}$ HAP-200 (coralline hydroxyapatite obtained by hydrothermal treatment of marine corals) and POVIAC $^{\circledR}$ (polymeric matrix based on PVAc), commercial trade marks were mixed with a natural product from the Cuban sea costs, i.e. calcium carbonate from Porites Porites coral, to obtain a novel bioactive composite with potential use as bone restoration material. The samples were characterized by physical-chemical (FTIR, XRD, SEM, EDS) and mechanical studies. It was shown that there is no chemical interaction between the inorganic filler and the polymer matrix, each conserving the original properties of the raw materials. The studied formulation had a compressive strength similar to that reported for trabecular bone. Scanning electron microscopy examination revealed that the addition of $\mathrm{CaCO}_{3}$ induces a change on the morphologic structure of the composite obtained after 30 days of SBF immersion. These composites generate novel biomaterials capable of promoting the deposition of a new phase, a Ca-P layer due to the bioactivity of a $\mathrm{Ca}^{2+}$ precursors.
\end{abstract}

Keywords: polyvinyl acetate, hydroxyapatite coralline, calcium carbonate, composite

\section{Introduction}

Over the past two decades many synthetic bone substitutes have been made, almost all of them, based on calcium phosphate, due to their excellent biocompatibility. Particularly, coralline hydroxyapatite is currently used in clinical applications as a bone substitute for medical applications, because its chemical composition and tridimensional porous morphology is very similar to human bone $e^{1,2}$. The coralline hydroxyapatite particles tend to migrate under externally applied forces during the healing period.

Numerous bioresorbable materials have been investigated for tissue repair, including natural ${ }^{3,4}$, and synthetic polymers ${ }^{5-9}$. One of the possible solutions to this problem is to combine the coralline hydroxyapatite particles with collagen ${ }^{10}$, chitosan ${ }^{11}$, polylactic acid $(\mathrm{PLA})^{7,8}$, polyglycolic acid (PLG) ${ }^{6}$, and polyvinyl acetate ${ }^{5-12}$.

Many practical advantages arise when using synthetic scaffolds, because precise engineering of material composition and micro and macrostructure is possible. This allows adequate control of scaffold properties, thus creating optimal conditions for cell survival and proliferation, after bone tissue formation ${ }^{6}$.

However, some problems have been encountered regarding the use of these polymers in tissue engineering applications due to the release of acidic degradation products leading to inflammatory responses ${ }^{5-9}$. Another limitation in the use of biodegradable polymers (i.e. PLG, PLA and its combinations) is the lack of bioactivity, in particular for bone tissue applications, if not used as composites ${ }^{13}$.

If biodegradability and bioactivity are to be combined in engineering an optimized tissue scaffold, then the composite design offers an exceptional opportunity: the preparation of bioresorbable and bioactive scaffolds with tailored physical and mechanical properties ${ }^{14}$. Moreover, composites can be engineered in such a way that their resorption rate is similar to the new tissue formation rate.
Various approaches to the development of bioresorbable and bioactive composites for tissue engineering applications are being investigated worldwide in different scaffold architectures ${ }^{14,15}$.

Specifically, the bioactivity of "Poliapatita" has been investigated as a resource for its best performance in bone tissue restoration. "Poliapatita" samples immersed in SBF for regular times between 1and 28 days, showed a good bioactivity. This capability was checked by SEM + EDS and progressive decrease of calcium and phosphorus concentration was observed, higher in case of phosphorus. In the first 7 days in SBF the rate of ionic deposition is quite fast and in the following days, as the $\mathrm{Ca}-\mathrm{P}$ layers increase, the rate of ionic deposition decreases with time ${ }^{16}$.

Composites slightly different from the original PMMA cements were evaluated for restoration of bone tissue. Modifications such as addition of vinyl acetate and HAP-200 induced a decrease of the mechanical properties of the classical PMMA bone acrylic cements. These changes in the formulation increase the bioactivity (subsequently, degradation, capability as drug delivery system, etc.), but compromise the performance as material for bone restoration ${ }^{17}$.

Several other reports about the influence of chemical composition, morphology, particle size distribution and molecular weight on the final properties of the bone cements were published. The addition of calcium generators (HAP-200/HA 3 and/or $\mathrm{CaCO}_{3}$ ) reduces the peak temperature and setting times, rising the bioactivity and the drug delivery ability of materials ${ }^{18,19}$.

The components used in the manufacturing of "Poliapatita" leave many $\mathrm{Ca}^{2+}$ ions in the formulation., The biological activity will increase, because calcium carbonate from coral is more bioresorbable ${ }^{20}$, and in vivo bone reconstruction could be significantly improved $^{21-23}$. 
Recent studies showed that a composite formed by POVIAC ${ }^{\circledR /}$ $\mathrm{CaCO}_{3} / \mathrm{HAP}-200$ is a good candidate as bone restoration material and can also be considered as a matrix for the delivery of drugs such as acetylsalicylic acid and cephalexin ${ }^{24-26}$.

In the present work novel bioactive and bioresorbable composite materials were prepared and characterized using polyvinyl acetate $\left(\right.$ POVIAC $\left.^{\circledR}\right)$ impregnated with bioresorbable calcium carbonate and bioactive coralline hydroxyapatite (HAP-200) particles. The materials are intended as composites for bone tissue engineering applications.

\section{Materials and Methods}

\subsection{Materials}

Calcium carbonate (Aragonite) was obtained from marine corals of the Cuban coralline barrier and poly (vinyl acetate) (POVIAC ${ }^{\circledR}$ ) (MW $=24400, \leq 2 \%$ residual monomer) was obtained in the National Center Scientific Research (Cuba) by in house procedures ${ }^{27}$. The HAP-200 coralline hydroxyapatite used in this study was prepared in the National Center Scientific Research (Cuba), by hydrothermal reaction ${ }^{28}$.

\subsection{Preparation of the POVIAC®/CaCO $/$ HAP-200 composite}

POVIAC ${ }^{\circledast} / \mathrm{CaCO}_{3} / \mathrm{HAP}-200$ composite scaffolds were prepared using compression molding and thermal processing. Initially, POVIAC ${ }^{\circledR}$ powders were dissolved in ethanol at room temperature, then the requested fractions of $\mathrm{CaCO}_{3}$ and HAP-200 particles were gradually added to the POVIAC ${ }^{\circledR}$ solution and thoroughly mixed for 1 hour (POVIAC ${ }^{\circledast} / \mathrm{CaCO}_{3} / \mathrm{HAP}-200=1 / 2 / 7$; w/w/w). Later, the mixture was dried at $90{ }^{\circ} \mathrm{C}$ under vacuum to remove residual organic solvents. Finally, for in vitro experiments, the composite was compacted using an axial compression mold at $10 \mathrm{MPa}$ for 1 minute. The compact disks had dimensions of $13 \mathrm{~mm}$ in diameter and $6,5 \mathrm{~mm}$ in thickness.

\subsection{In vitro studies in $S B F$ and physical-chemical and mechanic characterization}

POVIAC ${ }^{\circledR} / \mathrm{CaCO}_{3} / \mathrm{HAP}-200$ composite samples were characterized by Fourier-transform infrared (FT-IR) spectroscopy, $\mathrm{X}$-ray diffraction (XRD). Scanning electron microscopy (SEM) equipped with an energy dispersive spectrometer (EDS), was employed to examine the morphology, pore size and pore distribution of the samples; they were gold-coated and observed at an accelerating voltage of $20 \mathrm{kV}$.

The compressive strength (CS) testing was conducted on the composite disks using a universal machine test (MTS 810 Material Test System), at room temperature with a crosshead speed of $1 \mathrm{~mm} / \mathrm{min}$. The reported results are an average of the values from five samples.

In vitro studies in simulated body fluid (SBF) were carried out using the SBF composition and the standard procedures described by Kokubo in $2006^{29}$. Composites were immersed in $10 \mathrm{~mL}$ of SBF for 30 days at $37{ }^{\circ} \mathrm{C}$ and, every 72 hours in the first 15 days and every week in the last 15 days, the liquid phase was replaced with $10 \mathrm{~mL}$ of fresh SBF. After immersion in SBF the samples were characterized using XRD, FT-IR and SEM to verify whether HA was formed on the surfaces of the composites.

\section{Results and Discussion}

\subsection{Characterization of POVIAC®/CaCO$/$ HAP-200 composite}

The structures of the composite were analyzed using FT-IR spectroscopy, as shown in Figure 1.

Characteristic structural bands of POVIAC ${ }^{\circledR}, \mathrm{CaCO}_{3}$ and HAP-200 were observed in the composite spectrum. The vibration bands at ca. 2975 and $2852 \mathrm{~cm}^{-1}$ can be attributed to the asymmetric $\left(\mathrm{V}^{\text {as }}\left(\mathrm{CH}_{3}\right)\right)$ and symmetric $\left(\mathrm{V}^{\mathrm{s}}\left(\mathrm{CH}_{3}\right)\right)$ stretching of $\mathrm{CH}_{3}$ respectively, the band at $2927 \mathrm{~cm}^{-1}$ corresponds to the $\mathrm{CH}_{2}\left(\mathrm{~V}^{\text {as }}\left(\mathrm{CH}_{2}\right)\right)$ asymmetric stretching. The band at $1740 \mathrm{~cm}^{-1}$ is due to the $\mathrm{CO}$ group stretching $(\mathrm{v}(\mathrm{C}=\mathrm{O}))$ and that at $1245 \mathrm{~cm}^{-1}$ corresponds to the stretching vibration of the C-O-C group $(v(C-O-C))$, confirming the presenze of the typical side chains of $\mathrm{PVAc}^{30}$. Phosphate characteristic bands where observed at: $472 \mathrm{~cm}^{-1} \mathrm{v}_{2}\left(\mathrm{PO}_{4}^{3-}\right)$, at 569 and $601 \mathrm{~cm}^{-1} \mathrm{v}_{4}\left(\mathrm{PO}_{4}^{3-}\right)$, at $960 \mathrm{~cm}^{-1}$ and at 1088 and $1041 \mathrm{~cm}^{-1} v_{1}\left(\mathrm{PO}_{4}^{3-}\right)$, and $v_{3}\left(\mathrm{PO}_{4}^{3-}\right)$. These bands indicate the classification of the polyhedrons of $\mathrm{PO}_{4}{ }^{3-}$ in the structure of the hydroxyapatite ${ }^{31}$. Besides, at $3570 \mathrm{~cm}^{-1}$ the main $\mathrm{v}\left(\mathrm{OH}^{-}\right)$vibration is observed together with the bands at 3450 due to hydrogen bonded water molecules adsorbed during the preparation process. The band at $633 \mathrm{~cm}^{-1}$ is attributed to the $\mathrm{OH}^{-}$groups $(\delta)^{31}$ and the band at ca. $854 \mathrm{~cm}^{-1}$ may be attributed to the characteristic carbonate out-of-plane bending $\left(v_{2}\right.$ mode) vibrations of aragonite. The pair of bands at ca. 713 and $700 \mathrm{~cm}^{-1}$ may be assigned to the in-plane bending modes $\left(v_{4}\right.$ mode $)$ which are characteristic of the aragonite structure. The band corresponding to the $v_{1}$ vibration mode is masked by the doublet corresponding to $\mathrm{v}_{3}\left(\mathrm{PO}_{4}{ }^{3-}\right)$. No vibration bands characteristic of Calcite and Vaterite were detected in the FTIR spectrum, further demonstrating that the coral rods are pure aragonite ${ }^{32}$.

Figure 2 shows the XRD patterns of the POVIAC ${ }^{\circledR} / \mathrm{CaCO}_{3} /$ HAP-200 composite powder. By comparison with the JCPDS files No.71-2396 and No.09-0432, the diffraction peaks can be well identified as due to orthorhombic aragonite with lattice parameters of $\mathrm{a}_{0}=4,961 \AA, \mathrm{b}_{0}=7,970 \AA, \mathrm{c}_{0}=5,739 \AA$, and space group Pmcn and hexagonal syntetic hydroxyapatite with lattice parameters of $\mathrm{a}_{0}=\mathrm{b}_{0}=9,418 \AA, \mathrm{c}_{0}=6,884 \AA$, and space group P63/m respectively.

Both in the FT-IR spectra and in the XRD patterns, no significant changes or shifts in the characteristic bands and in the diffraction peaks were observed in the composite biomaterial with respect to the

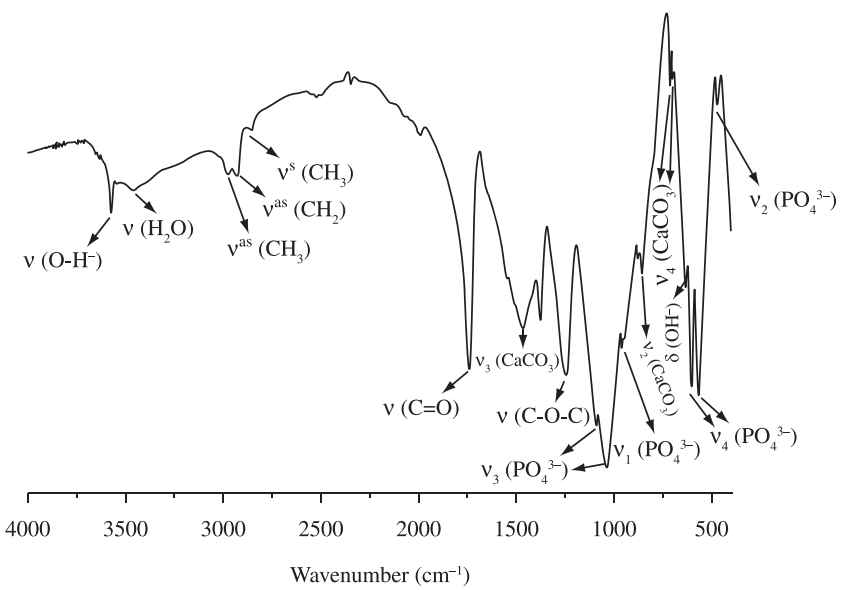

Figure 1. FT-IR spectra of the POVIAC $₫ / \mathrm{CaCO}_{3} / \mathrm{HAP}-200$ composite. 


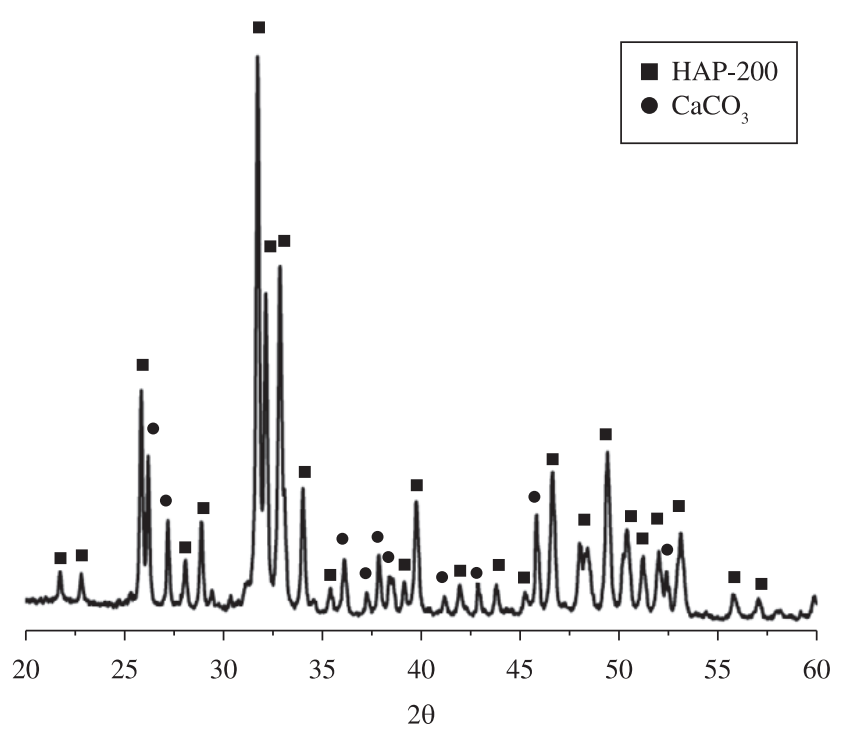

Figure 2. X-ray diffraction patterns of $\mathrm{POVIAC} / \mathrm{CaCO}_{3} / \mathrm{HAP}-200$ composite starting components (POVIAC ${ }^{\circledR}, \mathrm{CaCO}_{3}$ and HAP-200), suggesting that no chemical reactions occurred between the mixed components, which conserve the original properties of the raw materials. The compact structure of the POVIAC ${ }^{\circledast} / \mathrm{CaCO}_{3} / \mathrm{HAP}-200$ composite is reflected in the mechanical properties of the obtained composite. This composite present a value of $\mathrm{CS}=20 \pm 2 \mathrm{MPa}$, a value in the range observed for trabecular bone (3-20 MPa) $)^{33-34}$. According to recent reports, the percentage of diminution of mechanical properties by immersion in biological fluids of similar materials was $25 \%{ }^{[16]}$. Then we can evaluate that the CS of our formulation after inmersion would be $15 \mathrm{MPa}$ approximately.

\subsection{In vitro study}

The microscopic observation of the external surfaces showed that the particles of HAP-200 and $\mathrm{CaCO}_{3}$ are agglutinated by the POVIAC ${ }^{\circledR}$, and a compact block structure is formed (Figure $3 \mathrm{a}$ and $3 \mathrm{~b}$ ). It can also be seen that the composites have a low porosity and the structure of the material is rather dense.

Figures $3 \mathrm{c}$ and $3 \mathrm{~d}$ show that after 30 days in SBF the quantity of pores and the external morphology of the biomaterial composite

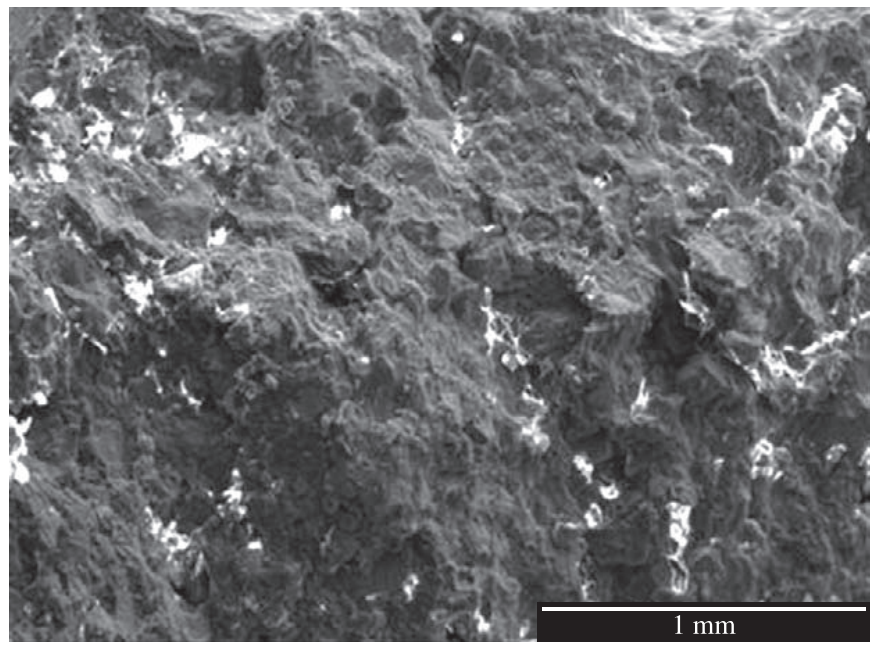

(a)

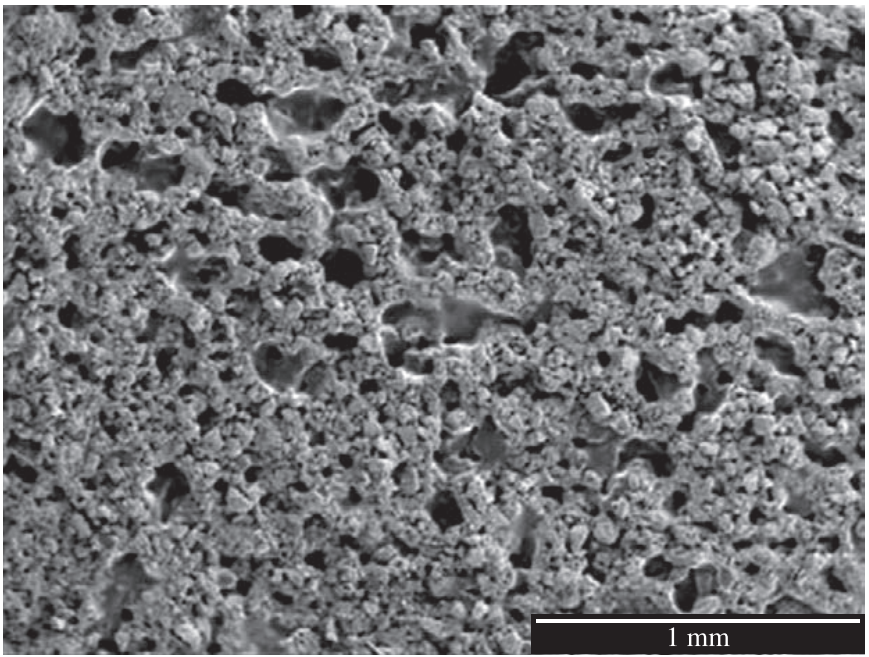

(c)

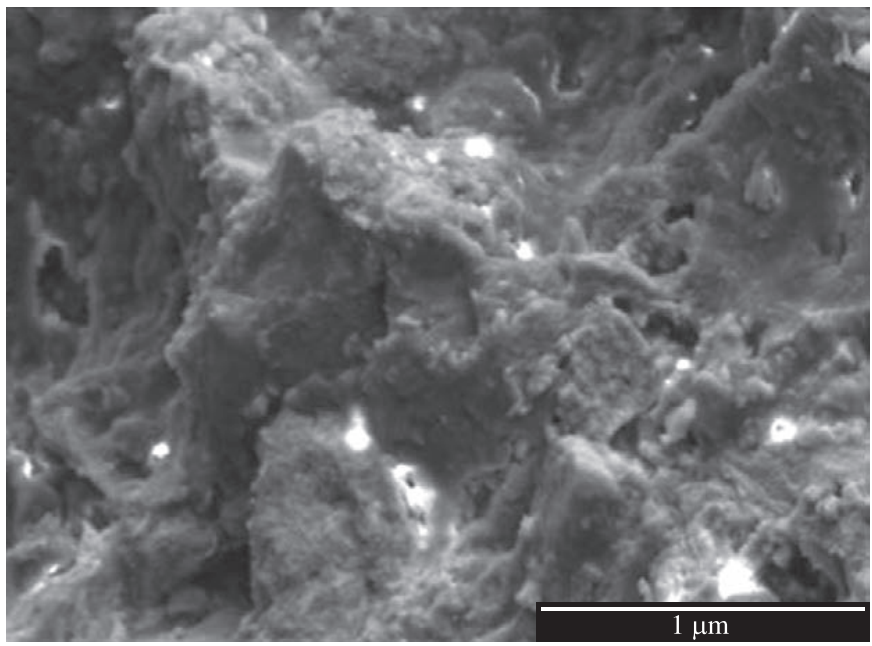

(b)

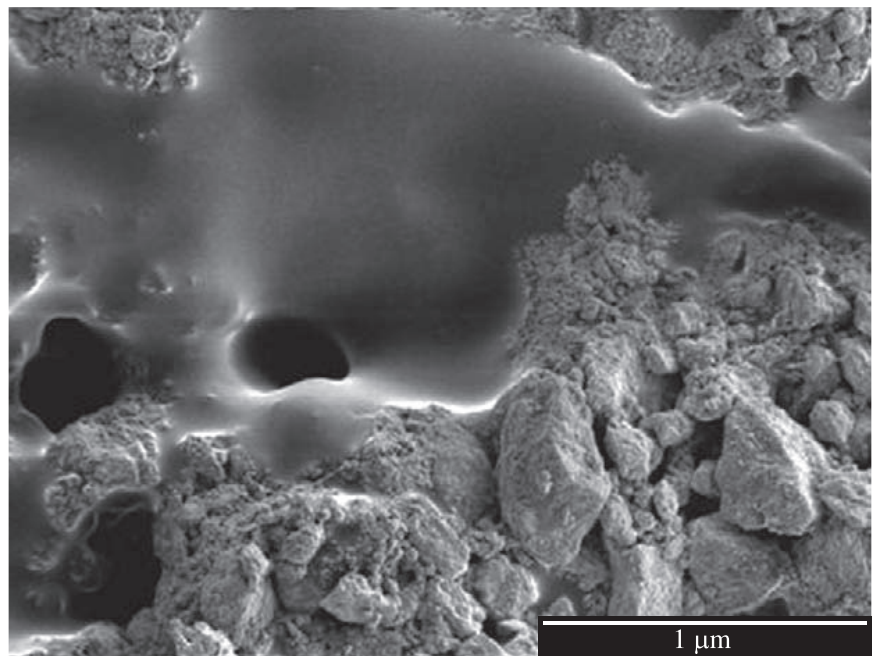

(d)

Figure 3. Surface morphology of the composite by SEM analysis: before immersion in SBF at different magnifications: a) $75 x$; b) $500 x$; after soaking in SBF for 30 days at different magnifications: c) $75 x$; and d) 500x. 
is significantly different, because of the partial degradation of the calcium carbonate. At the surface of this formulation an erosion phenomenon takes place, causing an increase in the porosity of the biomaterial. This increment could be very advantageous, since it would facilitate the growth of new bone tissue into the implanted material, favoring the process of bone integration.

Moreover, after 30 days of SBF immersion, it can be seen how on the surface of the whole formulation cavities (Figure 3d) were opened, limited by calcium phosphate and carbonate particles. EDX analysis inside one of the above cavities proved that their surface is rich in polymer phase (Figure 4a), as indicated by the low calcium and phosphorus content and the high carbon and oxygen content. Instead, the areas near these caves are rich in the inorganic phase, as shown by the significant increase in phosphorus and calcium content (Figure 4b).

The inorganic phase rich in calcium and phosphorus can be seen at higher magnification $(10000 \times)$ in Figure 5a. In this case it can be seen that, after 30 days of SBF immersion, the surface of the composite biomaterial is completely covered by a continuous layer. This layer is formed by the deposition of a new, calcium phosphate phase,

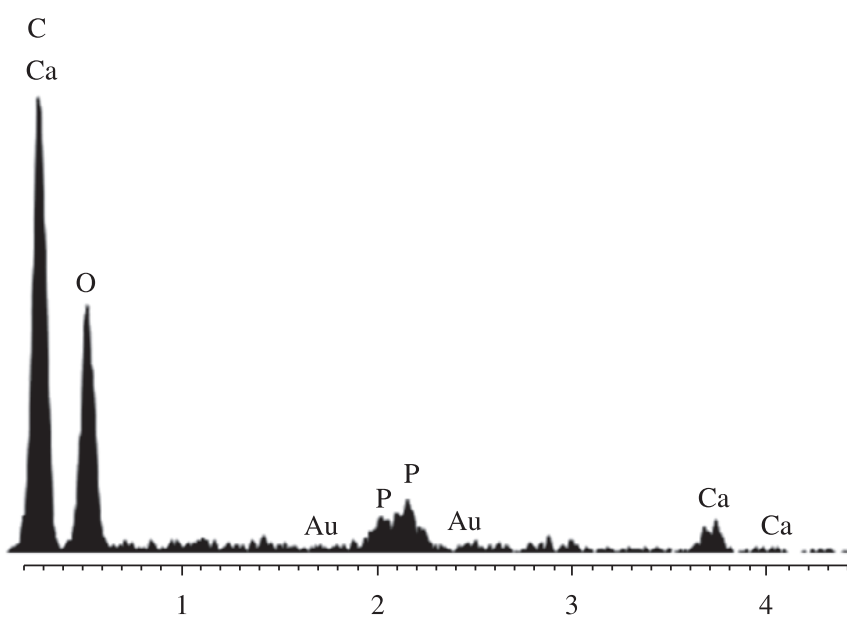

Full scale 258 cts Cursor: $4.343 \mathrm{keV}$ (1 cts)

(a)

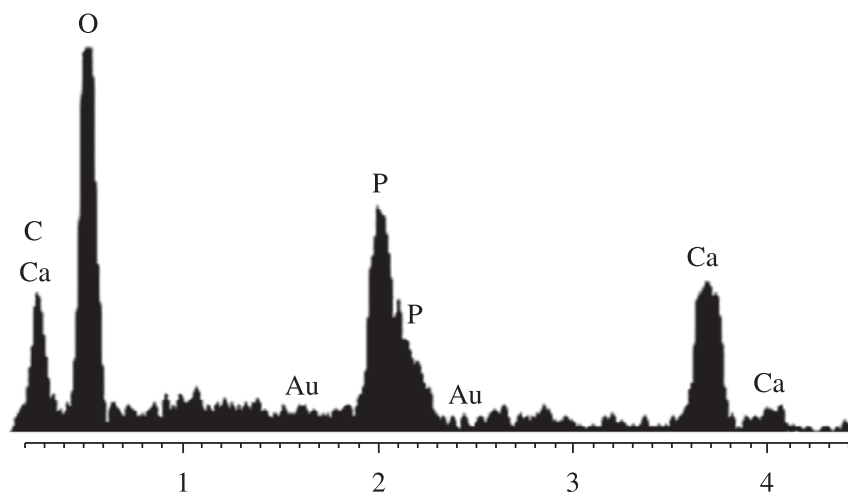

Full scale 258 cts Cursor: $4.343 \mathrm{keV}$ ( $1 \mathrm{cts})$

(b)

Figure 4. EDS spectrum of the composite after soaking in SBF for 30 days; a) inside the cavity; and b) near the cavity. characterized by arrangements of nanometric crystallites, typical of the formation of nanodispersed hydroxyapatite. Furthermore, in the region rich in POVIAC ${ }^{\circledR}$, agglomerates of nanometric hydroxyapatite crystals firmly attached to the polymer (Figure $5 \mathrm{~b}$ ) can be seen. This result is very important because so far there are no reports in the literature demonstrating the deposition of an apatite layer on polyvinyl acetate. It has been recently reported that the incorporation of vinyl acetate in PMMA containing composites increases the probability of apatite layer formation in acrylic bone cements ${ }^{17}$. The samples described in this work do not contain PMMA and the formation mechanism of those layers in the two cases is different. In PMMA-PVAc composites the presence of PVAc just increases the hydrophilic character of the acrylic bone cement, while the POVIAC ${ }^{\circledR}$ $\mathrm{CaCO}_{3} / \mathrm{HAP}$ formulation is designed from the very beginning as a hydrophilic composite.

The erosion phenomenon is due to the degradation of calcium carbonate particles present in the biomaterial composite as shown in Figure 6.

The analysis of the composites after immersion in SBF by FT-IR spectroscopy and X-ray diffraction, shows how the intensity of the

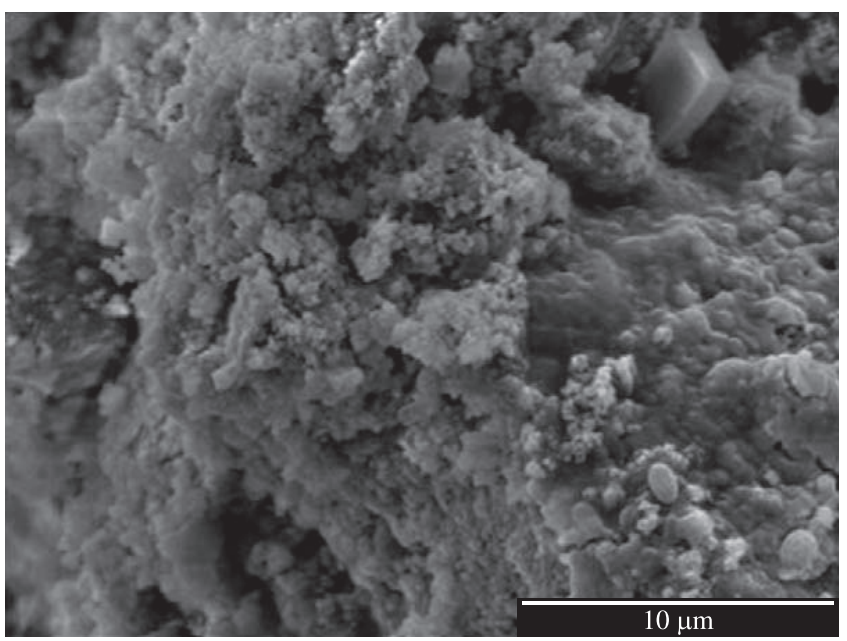

(a)

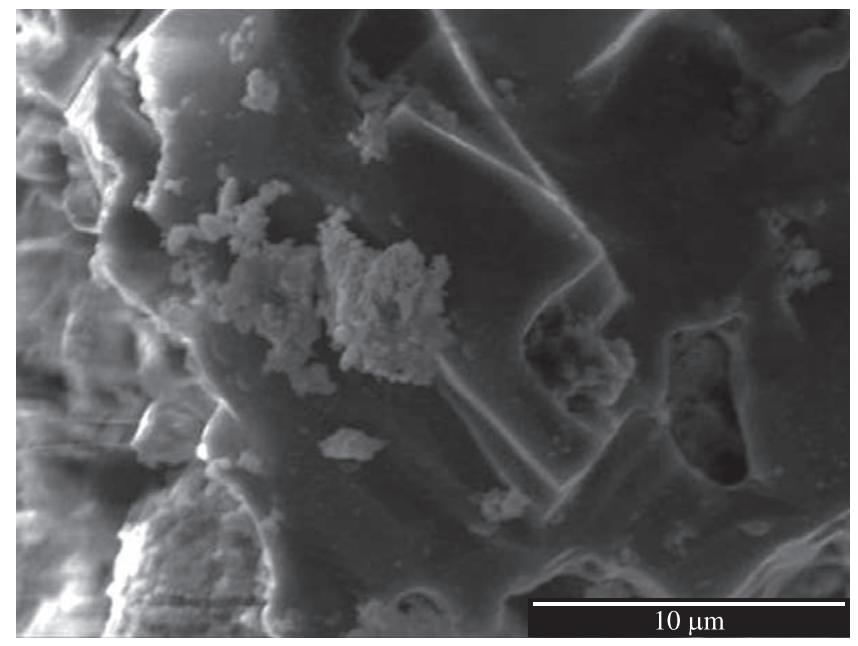

(b)

Figure 5. Surface morphology of POVIAC ${ }^{\circledast} / \mathrm{CaCO}_{3} / \mathrm{HAP}-200$ composite after immersion in SBF at higher magnification: a) near the cavity; and b) inside the cavity. 


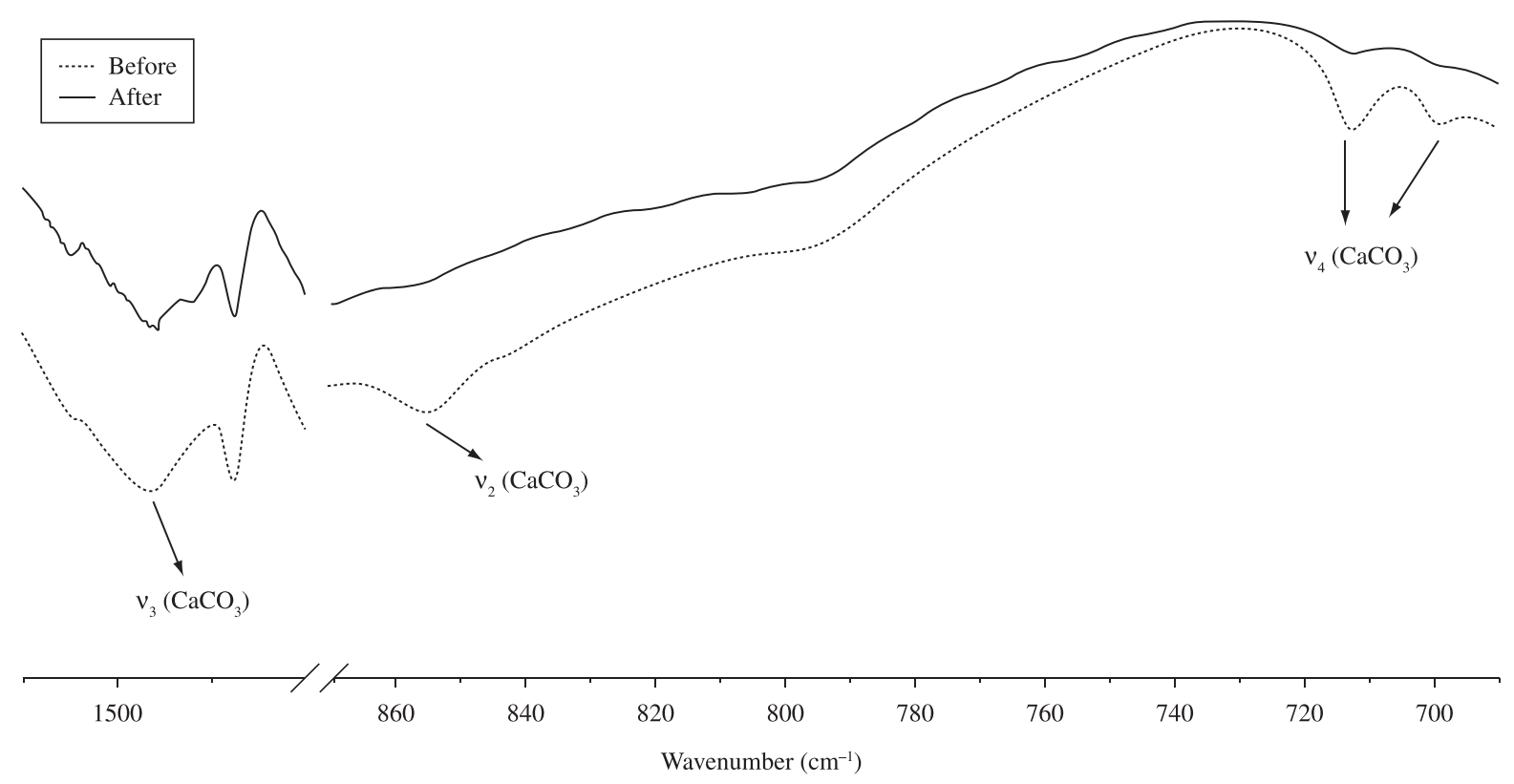

(a)
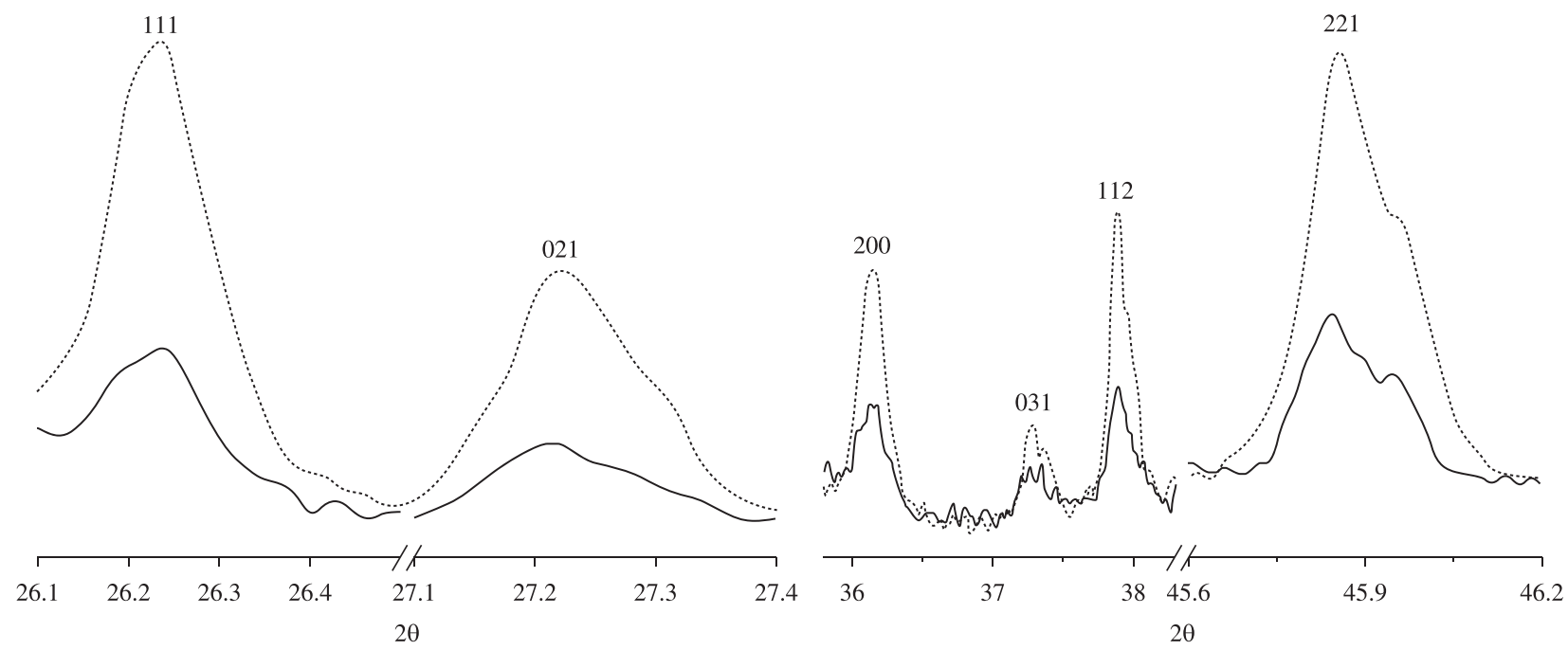

…. Before - After

(b)

Figure 6. Physicochemical characterizations of POVIAC ${ }^{\circledR} / \mathrm{CaCO}_{3} / \mathrm{HAP}-200$ composite, before and after soaking in SBF for 30 days: a) FT-IR analyses; and b) X-ray diffraction patterns.

calcium carbonate characteristic structural bands is considerably reduced (Figure $6 \mathrm{a}$ ), and the intensity of the typical $\mathrm{CaCO}_{3}$ reflexions in the XRD patterns is lowered in a similar way (Figure 6b).

\section{Conclusions}

A new organic-inorganic composite, that can be used as bone substitute in places where the requested compressive strength is similar to that reported for trabecular bone, was obtained. Physical-chemical characterization showed that there are no chemical interactions between the inorganic filler and the polymer matrix. Besides, the biomaterial compound has a dense morphological structure with a low porosity, which increases when in contact with $\mathrm{SBF}$ for a period of 30 days. It was observed that the biomaterial was able to favor the formation and the deposition over the inorganic filler and the polymeric matrix of a new calcium phosphate phase, with the typical features of nanometric hydroxyapatite.

\section{Acknowledgements}

We thank FONDAZIONE ISI for the financial support for this scientific project.

\section{References}

1. Roy DM and Linnehan SK. Hydroxyapatite formed from coral skeletal carbonate by hydrothermal exchange. Nature. 1974; 247(438):220-222.

2. Ripamonti U, Crooks J, Khoali L and Roden L. The induction of bone formation by coral-derived calcium carbonate/hydroxyapatite constructs. Biomaterials. 2009; 30(7):1428-1439. 
3. Piskin E. Biomaterials in different forms for tissue engineering: an overview. Material Science Forum. 1997; 250:1-14.

4. Zhang Y and Zhang M. Synthesis and characterization of macroporous chitosan/calcium phosphate composite scaffolds for tissue engineering. Journal of Biomedical Materials Research Part A. 2001; 55(3):304-312.

5. Maquet V and Jerome R. Design of macroporous biodegradable polymer scaffolds for cell transplantation. Material Science Forum. 1997; 250:15-42.

6. Agrawal CM, Athanasiou KA and Heckman JD. Biodegradable PLA-PGA polymers for tissue engineering in orthopadics. Material Science Forum. 1997; 250:115-129.

7. Schugens C, Maquet V, Grandfils C, Jerome R and Teyssie P. Biodegradable and macroporous polylactide implants for cell transplantation: I. Preparation of macroporous polylactide supports by solid-liquid phase separation. Polymer. 1996; 37(6):1027-1038.

8. Schugens C, Maquet V, Grandfils C, Jerome R and Teyssie P. Polylactide macroporous biodegradable implants for cell transplantation. II. Preparation of polylactide foams by liquid-liquid phase separation. Journal of Biomedical Materials Research Part A. 1996; 30(4):449-461.

9. Agrawal CM and Ray RB. Biodegradable polymeric scaffolds for musculoskeletal tissue engineering. Journal of Biomedical Materials Research Part A. 2001; 55(2):141-150.

10. Allard R, Bejui J and Huc A. Substitute bony matrix products promoting osteogenesis. United State Patent No. US5071436. 1991. Available from: http://www.boliven.com/patent/US5071436 Access in: 12/2009.

11. Sivakumar M and Panduranga Rao K. Preparation, characterization and in vitro release of gentamicin from coralline hydroxyapatite-gelatin composite microspheres. Biomaterials. 2002; 23(15):3175-3181.

12. Gonzalez R and Suzarte A. Composite biomaterial for bone implants. United State Patent No. 0053951. 2007. Available from: http://www. freepatentsonline.com/20070053951.html. Access in: 12/2009.

13. Schliephake H, Neukam FW, Hutmacher D and Becker J. Enhancement of bone in-growth into a porous HA-matrix using a resorbable polylactice membrane. Journal of Oral and Maxillofacial Surgery. 1994; 52(1):57-63.

14. Verheyen CCPM, de Wijn JR, Van Blitterswijk CA, de Groot K and Rozing PM. Hydroxyapatite/poly(l-lactide) composites: an animal study on push-out strengths and interface histology. Journal of Biomedical Materials Research Part A. 1993; 27(4):433-444.

15. Durucan $\mathrm{C}$ and Brown PW. Biodegradable hydroxyapatite-polymer composites. Advanced Engineering Materials. 2001; 3(5):227-231.

16. Castro $\mathrm{H}$ and Ledea O. Determinación de la bioactividad y la resistencia a la compresión de bloques de POLIAPATITA®. Química Nova. 2010; 33(4):891-894.

17. Brizuela N, Lopez M and González R. Cementos óseos acrílicos modificados con hidroxiapatita/acetato de vinilo. Caracterización mecánica, termoanálitica y bioactividad in vitro. Polímeros. 2010; 20(2):98-106

18. López M, Fuentes G, González R, González J, Peón E and Toledo C. PMMA/Ca2+ Bone cements. Part I. Physico chemical and thermoanalytical characterization. Latin American Applied Research. 2008; 38(3):227-234.
19. Arias D and González R. Biomaterial de implante óseo compuesto de HAP-polivinilacetato. Revista CENIC Ciencias Químicas. 2004; 35(2):101-103.

20. Wikesjo UM, Lim WH, Razi SS, Sigurdsson TJ, Lee MB, Tatakis DN et al. Periodontal repair in dogs: a bioabsorbable calcium carbonate coral implant enhances space provision for alveolar bone regeneration in conjunction with guided tissue regeneration. Journal of Periodontology. 2003; 74(7):957-964.

21. Paul W and Sharma CP. Ceramic drug delivery: a perspective. Journal of Biomaterials Applications. 2003; 17(4):253-264.

22. Green D, Walsh D, Yang X, Mann S and Oreffo ROC. Stimulation of human bone marrow stromal cells using growth factor encapsulated calcium carbonate porous microspheres. Journal of Materials Chemistry. 2004; 14:2206-2213.

23. Green DW, Bolland BJRF, Kanczler JM, Lanham SA, Walsh D, Mann $\mathrm{S}$ et al. Augmentation of skeletal tissue formation in impaction bone grafting using vaterite microsphere biocomposites. Biomaterials. 2009; 30(10):1918-1927.

24. Aragón J, Brizuela N and González R. Perfil de liberación controlada de ASA en biomateriales compuestos de hidroxiapatita-POVIAC. Revista CENIC Ciencias Químicas. 2006; 37(3):179-181.

25. Aragón J, González R and Fuentes G. Cinética de liberación de cefalexiana desde un biomaterial compuesto por HAP-200/POVIAC/CaCO . Anales $_{3}$ de la Real Academia Nacional de Farmacia. 2009; 75(3):345-363.

26. Aragón J, González R, Nayrim B and Oliver L. Estudio cinético de liberación in vitro en un biomaterial compuesto por HAP-200/POVIAC/ $\mathrm{CaCO}_{3}$. Revista Iberoamericana de Polímeros. 2009; 10(2):119-130.

27. Suzarte A, Jordán G, Echevarría M, Iglesias G and Díaz E. Procedures for obtaining polymers derived from vinyl acetate and their uses. United State Patent No. 0306226. 2009. Available from: http://www.freepatentsonline. com/y2009/0306226.html. Access in: 12/2009.

28. González R, Handal E and Fernández J. Cinética de la reacción de transformación hidrotérmica del coral a hidroxiapatita. Química Nova. 1993;16(6):513-516.

29. Kokubo $\mathrm{T}$ and Takadama $\mathrm{H}$. How useful is SBF inpredicting in vivo bone bioactivity. Biomaterials. 2006; 27(15):2907-2915.

30. Gómez A. Estudio de Kollidon® $R R$ y su aplicación al diseño de suspensiones orales opiáceos. [Ph.D. Thesis]. Universidad de Granada; 2007. Available from: http://hera.ugr.es/tesisugr/17241212.pdf. Access in: $02 / 2010$.

31. Fowler BO. Infrared Studies of apatites. I. Vibrational assignments for calcium, strontium, and barium hydroxyapatites utilizing isotopic substitution. Inorganic Chemistry. 1974; 13(1):194-207.

32. Gen-Tao Z, Qi-Zhi Y, Jie N and Gu J. Formation of aragonite mesocrystals and implication for biomineralization. American Mineralogist. 2009; 94(2-3):293-302.

33. Comín M, Peris J, Prat J, Dejoz J, Vera P and Hoyos J. Biomecánica de la fractura ósea y técnicas de reparación. Valencia: Instituto de Biomecánica de Valencia; 1999.

34. Cowin SC. Bone mechanics handbook. Florida, Boca Raton: CRC Press; 2001. 